\title{
Menggali Potensi Sumber Pendapatan Asli Daerah Kabupaten Pegunungan Arfak Provinsi Papua Barat Melalui Analytical Hierarchy Process (AHP)
}

\author{
Muhammad Guzali Tafalas ${ }^{1}$ \\ ${ }^{1}$ Program Studi Ekonomi Pembangunan, Universitas Papua
}

Received: Desember 2018; Accepted: Januari 2019; Published: Maret 2019

\begin{abstract}
Abstrak
Kabupaten Pegunungan Arfak secara administratif terbentuk pada tahun 2012. Dengan berdirinya Kabupaten Pegunungan Arfak sebagai daerah otonomi baru maka segala bentuk tataran perekonomiannya sudah terpisah dari kabupaten induknya. Kabupaten Pegunungan Arfak sebagai suatu daerah otonom diharapkan memiliki kemampuan pengelolahan pendapatan asli daerah untuk membiayai penyelenggaraan pemerintahan daerahnya. Dalam mencapai kemampuan dalam kemandirian keuangan daerah tersebut perlu dilakukan optimalisasi sumbersumber pendapatan asli daerah. Hasil Analytical Hierarchy Process (AHP) terhadap penilaian beberapa alternatif kebijakan terkait optimalisasi sumber-sumber pendapatan asli daerah di Kabupaten Pegunungan Arfak adalah sebagai berikut: (1). meningkatkan kapasitas penerimaan melalui perencanaan yang lebih baik; (2). memperluas basis penerimaan; (3). meningkatkan efisiensi administrasi dan menekan biaya pemungutan; (4). memperkuat proses pemungutan dan (5). meningkatkan pengawasan. Keberhasilan pengelolaan pendapatan asli daerah tidak hanya semata diukur dari jumlah penerimaan yang dapat dicapai, tetapi sejauh mana pendapatan asli daerah tersebut dapat berperan menggerakan perekonomian masyarakat agar dapat bertumbuh kembang yang pada gilirannya dapat meningkatkan kesejahteraan masyarakat di kabupaten ini.
\end{abstract}

Kata kunci: otonomi daerah, pendapatan asli daerah, analytical hierarchy process (AHP)

\begin{abstract}
The Arfak Mountains Regency is administratively formed in 2012. With the establishment of the Arfak Mountains District as a new autonomous region, all forms of economic levels have been separated from the former regency. Arfak Mountains Regency as an autonomous region is expected to have the ability to manage regional own revenue to finance the administration of the regional government. In achieving the capability in regional financial independence, it is necessary to optimize the sources of regional revenue. The results of the Analytical Hierarchy Process (AHP) on the assessment of several alternative policies related to the optimization of sources of regional own revenue in the Arfak Mountains District, are as followed: (1). Increasing revenue capacity through better planning; (2). expanding revenue bases; (3). improving administrative efficiency and reducing collection costs; (4). strengthening collection processes and (5). improving controlling processes. The success of the management of regional own revenue is not only measured by the amount of revenue that can be achieved, but also by the extent to which the regional own revenue can play a role in driving the economy of the community so that it can improve the welfare of the community in this regency.
\end{abstract}

Keywords: special autonomy, regional own revenue, analytical hierarchy process (AHP)

How to Cite: Tafalas, M.G. (2019). Menggali Potensi Sumber Pendapatan Asli Daerah Kabupaten Pegunungan Arfak Provinsi Papua Barat Melalui Analytical Hierarchy Process (AHP). JFRES: Journal of Fiscal and Regional Economy Studies, 2 (1), 1 - 11 


\section{PENDAHULUAN}

Implementasi otonomi daerah membawa konsekuensi yang sangat besar dalam paradigma pengelolaan daerah. Otonomi daerah termasuk didalamnya adanya desentralisasi fiskal dimana daerah mempunyai kewenangan pengelolaan keuangan yang tinggi (Setiaji dan Adi, 2007). Dalam era otonomi ini, daerah dituntut untuk semakin meningkatkan kemandirian (keuangan) untuk membiayai berbagai belanja daerah.

Berlakunya Undang-Undang ini memberikan peluang yang lebih besar kepada daerah untuk lebih mengoptimalkan potensi yang ada, baik menyangkut sumber daya manusia, dana maupun sumber daya lain yang merupakan kekayaan daerah. Hakekat dari otonomi daerah adalah adanya kewenangan yang lebih besar dalam pengurusan maupun pengelolaan daerah, termasuk didalamnya pengelolaan keuangan.

Penyerahan urusan pemerintahan dan pembangunan daerah kabupaten/kota memberikan kewenangan kepada daerah dalam mencari sumbersumber pembiayaan untuk menyelenggarakan urusan-urusan tersebut. Sumber-sumber pembiayaan itu berasal dari Pendapatan Asli Daerah (PAD), bantuan pemerintah pusat dan sumber-sumber lain yang sah. Di antara berbagai sumber pembiayaan menjadi tiga tipe ekosistem hutan utama, yaitu: hutan hujan dataran rendah (lowland forest) (<300 meter), hutan hujan kaki gunung (foothill forest) $(300-1.000$ meter), dan hutan hujan lereng pegunungan (lower mountain forest) (1.000 - 2.800 meter).

Perbedaan zona ekosismen itu membuat kawasan Pegunungan Arfak kaya akan keanekaragaman hayati bernilai tinggi. Hamparan vegetasi hutan tropis di kawasan ini telah menjadi istana penyedia kehidupan bagi sedikitnya 12.000 jiwa empat suku asli yang bermukim disini yaitu: Hatam, Meyakh, Sough dan Moley. Di Pegunungan Arfak ini terdapat gunung tertinggi di Papua Barat, yaitu Gunung Umsini $(2.950 \mathrm{~m} \mathrm{dpl})$, dimana di gunung ini terdapat dua danau, yaitu Danau Anggi Gita (2.500 ha) dan Anggi Gigi (1.800 ha). Karena perannya yang demikian penting bagi flora, fauna dan manusia, maka melalui Keputusan Menteri Kehutanan No. 783/Kpts-II/1992 tertanggal 11 Agustus 1992, Pegunungan Arfak ditetapkan menjadi kawasan Cagar Alam Pegunungan Arfak (CAPA). Dalam keputusan itu ditetapkan bahwa kawasan ini membentang seluas 68.325 hektar mencakup 8 wilayah tersebut, PAD merupakan sumber yang mempunyai arti penting karena mencerminkan kemandirian daerah dalam menyelenggarakan otonomi daerah. Kenyataan menunjukkan banyak daerah yang masih tergantung pada bantuan pemerintah pusat dalam pembiayaannya karena minimnya PAD.

Kabupaten Pegunungan Arfak merupakan daerah pemekaran dari Kabupaten Manokwari yang dibentuk berdasarkan Undang-Undang Republik Indonesia Nomor 24 Tahun 2012 Tentang Pembentukan Kabupaten Pegunungan Arfak di Provinsi Papua Barat. Pembentukan Kabupaten Pegunungan Arfak dimaksudkan untuk mendorong peningkatan pelayanan di bidang pemerintahan, pembangunan, dan kemasyarakatan, serta kemampuan dalam pemanfaatan potensi daerah untuk penyelenggaraan otonomi daerah. Pegunungan Arfak adalah gugusan gunung yang membentang di bagian kepala burung Pulau Papua. Memiliki ketinggian antara 15 meter hingga 2.950 meter diatas permukaan laut (dpl). Berdasarkan klasifikasi ketinggian, kawasan Pegunungan Arfak memiliki perwakilan tipe ekosistem beragam yang terbagi

distrik, seperti: Menyambouw, Membey, Hingk, Tanah Rubuh, Warmare, Manokwari Selatan, Ransiki dan Oransbari (manokwari.bpk.go.id, 2014).

Dengan potensi sumberdaya alam dan manusia serta sosial budaya yang dimiliki, pengelolahan potensi sumberdaya alamnya akan menjadi sumber potensi PAD yang cukup besar. Dengan berkembangnya sektor bisnis, investasi dan perdagangan barang/jasa yang sangat pesat sudah dapat dipastikan melalui setoran pajak maupun restribusi diharapkan akan mampu mendongkrak PAD Kabupaten Pegunungan Arfak dengan baik. Dengan seluruh kondisi di atas, maka timbul pertanyaan apakah sumbersumber pendapatan asli daerah yang terjadi telah didasarkan kepada strategi kebijakan pembangunan yang tepat, yaitu strategi yang memberikan dampak yang optimal bagi pertumbuhan ekonomi dan peningkatan kesejahteraan masyarakat. Karena untuk melaksanakan pembangunan dengan sumber daya keuangan daerah yang terbatas sebagai konsekuensinya perlu difokuskan kepada peningkatan sumber-sumber pendapatan asli daerah yang memberikan dampak pengganda 
(multiplier effect) yang besar terhadap perencanaan pembangunan dan meningkatkan pertumbuhan ekonomi daerah secara keseluruhan. Penelitian ini mencoba mengkaji sumber-sumber pendapatan asli daerah Kabupaten Pegunungan Arfak sehingga dapat dijadikan pertimbangan dalam perumusan kebijakan otonomi pengelolahan keuangan daerah Kabupaten Pegunungan Arfak di Provinsi Papua Barat dalam menunjang perencanaan pembangunan dan meningkatkan pertumbuhan ekonomi.

\section{TINJAUAN PUSTAKA}

\section{Pendapatan Asli Daerah (PAD)}

Pendapatan Asli Daerah (PAD) merupakan salah satu sumber dari pendapatan daerah. Dalam memenuhi prinsip otonomi yang nyata dan bertanggungjawab, kepada daerah diberikan sumber-sumber keuangan untuk membiayai berbagai tugas dan tanggungjawabnya sebagai daerah otonom. Klasifikasi PAD yang terbaru berdasarkan Permendagri Nomor 13 Tahun 2006 terdiri dari pajak daerah, retribusi daerah, hasil pengelolaan daerah yang dipisahkan, dan lainlain pendapatan asli daerah yang sah. Jenis pajak daerah dan retribusi daerah dirinci menurut objek pendapatan sesuai dengan undang-undang tentang pajak daerah dan retribusi daerah. Jenis hasil pengelolaan kekayaan daerah yang dipisahkan dirinci menurut objek pendapatan yang mencakup bagian laba atas penyertaaan modal pada perusahaan milik daerah/BUMD, bagian laba atas penyertaan modal pada perusahaan milik pemerintah/BUMN, dan bagian laba atas penyertaan modal pada perusahaan milik swasta atau kelompok usaha masyarakat.

Sektor pemerintahan membutuhkan data dan informasi, antara lain untuk pengelolaan lingkungan hidup, sumber daya alam, sumber daya air, pengendalian pertumbuhan daerah urban, penegakan hukum, dan penurunan kemiskinan. Baik secara internasional maupun nasional, sekitar $80 \%$ pengambilan keputusan dan kebijakan pemerintah didasarkan pada data dan informasi. Untuk upaya mendukung pelaksanaan good governance juga diperlukan kemudahan untuk mengakses data dan informasi secara efektif dan efisien, cepat, dan akurat. Oleh karena itu, diperlukan manajemen informasi pada beberapa tingkatan administrasi pemerintahan daerah.
Untuk mewujudkan itu semua dibutuhkan jaringan mengumpulan data secara terpadu di daerah beserta analisis data sebagai dukungan dalam pelaksanaan perencanaan dan evaluasi pembangunan daerah. Akibat ketidak jelasan informasi maka dapat berakibat:

1) Kualitas perencanaan rendah, Perencanaan dan Kebijakan tidak didukung dengan data dan informasi yang memadai;

2) Semakin minimnya data dan informasi perkembangan daerah.

3) Tidak adanya sistem, instrumen dan indikator yang jelas dan terukur untuk menilai kinerja penyelenggaraan pembangunan di daerah.

Data dan Informasi merupakan dua faktor penting untuk mendukung tercapainya kualitas perencanaan dan pengendalian pembangunan yang dapat dihandalkan. Data dan Informasi merupakan fakta penting untuk perumusan kebijakan dan pengambilan keputusan oleh pimpinan. Kelengkapan jenis data dan kemutakhiran data akan dapat memberikan hasil yang memuaskan bagi semua pihak terhadap hasil perencanaan dan pengendalian yang dilaksanakan.

Makin pentingnya peranan penelitian dan pengembangan dalam otonomi daerah diperlukan pengembangan sistem database Potensi Pendapatan Asli Daerah (PAD). Pemerintah dihadapkan terhadap berbagai tantangan dan permasalahan yang makin berat dan berdemensi kompleks. Berbagai kebijakan menyangkut PAD haruslah didasarkan atas pertimbangan-pertimbangan yang merupakan solusi yang terbaik dan seminimal mungkin tidak menimbulkan akses negatif di kemudian hari (dalam jangka panjang). Untuk meningkatkan potensi Pendapatan Asli Daerah (PAD) dibutuhkan suatu sistem yang terpadu yang merupakan rangkaian sistem dan informasi penelitian dan pengembangan yang berbasis pada daerah serta berorientasi pada kesejahteraan rakyat.

\section{Sumber-sumber PAD}

Pendapatan Asli Daerah adalah penerimaan daerah dari sektor pajak daerah, retribusi daerah, hasil perusahan milik daerah, hasil kekayaan daerah yang dipisahkan dan lain-lain PAD yang sah. Pendapatan Asli Daerah (PAD) merupakan suatu pendapatan yang menunjukkan suatu kemampuan daerah menghimpun sumber sumber dana untuk membiayai kegiatan rutin maupun pembangunan. Jadi pengertian dari pendapatan asli daerah dapat dikatakan sebagai 
pendapatan rutin dari usaha-usaha pemerintah daerah dalam memanfaatkan potensi-potensi sumber keuangan daerahnya untuk membiayai tugas dan tanggungjawabnya.

Adapun sumber-sumber Pendapatan Asli Daerah secara rinci dapat dijelaskan sebagai berikut :

\section{A) Pajak Daerah}

Pajak daerah adalah iuran wajib yang dilakukan oleh orang pribadi dan badan kepada daerah tanpa imbalan langsung yang seimbang, yang dapat dipaksakan berdasarkan peraturan perundang-undangan yang berlaku, yang digunakan untuk membiayai penyelenggaraan pemerintah daerah dan pembangunan daerah, yang meliputi :
a. Pajak Hotel
b. Pajak Restoran Pajak Hiburan
c. Pajak Reklame
d. Pajak Penerangan Jalan
e. Pajak Mineral Bukan Logam dan Batuan
f. Pajak Parkir
g. Pajak Air Tanah
h. Pajak Sarang Burung Walet
i. Pajak Bumi dan Bangunan Perdesaan dan Perkotaan
j. Bea Perolehan hak Atas Tanah dan Bangunan

B) Retribusi Daerah

Retribusi Daerah adalah pungutan daerah sebagai pembayaran atas jasa atau pemberian izin tertentu yang khusus disediakan dan atau diberikan oleh Pemda untuk kepentingan orang pribadi atau badan. Restribusi Daerah meliputi :

a. Retribusi Jasa Umum :

1) Pelayanan kesehatan

2) Pelayanan persampahan/kebersihan

3) Penggantian biaya cetak Kartu Penduduk dan Akte Catatan Sipil

4) Pelayanan pemakaman dan pengabuan mayat

5) Pelayanan parkir di tepi jalan umum

6) Pelayanan pasar

7) Pengujian kendaraan bermotor

8) Pemeriksaan alat pemadam kebakaran

9) Penggantian biaya cetak peta

10) Penyediaan dan/atau penyedotan kakus

11) Pengolahan limbah cair

12) Pelayanan tera/tera ulang

13) Pelayanan pendidikan

14) Pengendalian menara telekomunikasi

b. Retribusi Jasa Usaha :
1) Pemakaian kekayaan daerah

2) Pasar grosir dan/atau pertokoan

3) Tempat pelelangan

4) Terminal

5) Tempat khusus parkir

6) Tempat penginapan/pesanggrahan/villa

7) Rumah potong hewan

8) Pelayanan kepelabuhanan

9) Tempat rekreasi dan olah raga

10) Penyeberangan di air

11) Penjualan produksi usaha daerah

c. Retribusi Jasa Perijinan Tertentu :

1) Izin mendirikan bangunan

2) Izin tempat penjualan minuman beralkohol

3) Izin gangguan

4) Izin trayek

5) Izin usaha perikanan

C) Hasil Perusahaan Milik Daerah dan Hasil Pengelolaan Kekayaan Milik Daerah yang dipisahkan.

Jenis pendapatan dari hasil pengelolaan kekayaan daerah yang dipisahkan terdiri dari

a. Bagian laba atas penyertaan modal pada perusahaan milik daerah/BUMD

b. Bagian laba atas penyertaan modal pada perusahaan milik pemerintah/BUMN

c. Bagian laba atas penyertaan modal pada perusahaan milik swasta/kelompok usaha masyarakat

D) Lain-lain Pendapatan Asli Daerah Yang Sah Terdiri dari :

Jenis pendapatan ini meliputi objek pendapatan berikut ini :

a. Jasa giro

b. Pendapatan bunga

c. Penerimaan atas tuntutan ganti kerugian daerah

d. Penerimaan komisi, potongan ataupun bentuk lain sebagai akibat dari penjualan dan /atau pengadaan barang dan/atau jasa oleh daerah

e. Penerimaan keuntungan dari selisih nilai tukar rupiah terhadap mata uang asing

f. Pendapatan denda atas keterlambatan pelaksanaan pekerjaan

g. Pendapatan denda pajak

h. Pendapatan denda retribusi

i. Pendapatan hasil eksekusi atas jaminan

j. Pendapatan atas pengembalian

k. Fasilitas sosial dan fasilitas umum

1. Pendapatan dari penyelenggaraan pendidikan dan pelatihan 
m. Pendapatan dari Badan Layanan Umum Daerah (BLUD)

\section{METODE PENELITIAN}

Penelitian ini tidak menguji hipotesis atau tidak menggunakan hipotesa, melainkan hanya mendeskripsikan informasi informasi apa adanya sesuai variabel-variabel yang diteliti. Penelitian semacam ini sering dilakukan guna merekomendasikan kebijakan atau keputusan untuk melakukan tindakan-tindakan dalam melakukan tugasnya.

Pendekatan yang dikenakan tema penelitian ini agar sesuai dengan tujuan yang ingin dicapai menggunakan Mixed Method yaitu pendekatan penelitian kualitatif dan kuantitatif. Pendekatan penelitian kualitatif digunakan untuk menjawab permasalahan fenomena secara real yang tidak dapat diungkap tuntas hanya berdasarkan oleh data di lapangan. Sedangkan pendekatan penelitian yang bersifat kuantitatif adalah digunakan untuk menyempurnakan dan menguatkan penjelasan yang dijabarkan oleh sumber-sumber yang berkompeten dan relevan saat melakukan pengayaan informasi di lapangan.

Selanjutnya dalam penentuan prioritas kebijakan dalam menggali potensi sumber-sumber PAD digunakan analisis Analytical Hierarchy Process (AHP) atau Proses Hirarki Analitik. AHP dapat digunakan dalam memecahkan berbagai masalah diantaranya menentukan peringkat beberapa alternatif, melaksanakan perencanaan ke masa depan dan menetapkan prioritas pengembangan suatu kebijakan dan permasalahan kompleks lainnya.

Data yang diperlukan dalam kegiatan kajian sumber-sumber pendapatan asli daerah Kabupaten Pegunungan Arfak di Provinsi Papua Barat ini bisa bersifat data sekunder maupun data primer. Untuk keperluan data sekunder akan dikumpulkan dari Badan Pusat Statistik (BPS), Bappeda Provinsi Papua Barat, Dinas Pendapatan Daerah, atau pun dinas dan instansi terkait lainnya serta dari literatur, publikasi lainnya. Sedangkan untuk data primer akan dikumpulkan melalui observasi dan wawancara semi terstruktur.

\section{HASIL DAN PEMBAHASAN}

Optimalisasi Sumber-sumber $\quad$ PAD
Kabupaten Pegunungan Arfak
$\begin{aligned} & \text { Dinamika Sumber PAD } \\ & \text { Pegunungan Arfak }\end{aligned}$

Kabupaten Pegunungan Arfak sebagai suatu daerah otonom diharapkan juga memiliki kemampuan dalam keuangan daerah. Kabupaten Pegunungan Arfak harus memiliki kewenangan dan kemampuan untuk menggali sumber-sumber keuangan sendiri, mengelola dan menggunakan keuangan sendiri yang cukup memadai untuk membiayai penyelenggaraan pemerintahan daerahnya.

Berkaitan dengan hal tersebut, optimalisasi sumber-sumber PAD perlu dilakukan untuk meningkatkan kemampuan keuangan Kabupaten Pegunungan Arfak. Untuk itu diperlukan intensifikasi dan ekstensifikasi subyek dan obyek pendapatan. Dalam jangka pendek kegiatan yang paling mudah dan dapat segera dilakukan adalah dengan melakukan intensifikasi terhadap obyek atau sumber pendapatan daerah yang sudah ada dengan melakukan efektivitas dan efisiensi sumber atau obyek pendapatan daerah.

Secara umum, upaya yang perlu dilakukan oleh Pemerintah Daerah Kabupaten Pegunungan Arfak dalam rangka meningkatkan kemampuan keuangan daerah melalui optimalisasi sumbersumber pendapatan asli daerah, antara lain dapat dilakukan dengan cara-cara sebagai berikut :

1) Memperluas basis penerimaan; Tindakan yang dilakukan untuk memperluas basis penerimaan yang dapat dipungut oleh daerah, yang dalam perhitungan ekonomi dianggap potensial, antara lain yaitu mengidentifikasi pembayar pajak baru/potensial dan jumlah pembayar pajak, memperbaiki basis data objek, memperbaiki penilaian, menghitung kapasitas penerimaan dari setiap jenis pungutan.

2) Memperkuat proses pemungutan; Upaya yang dilakukan dalam memperkuat proses pemungutan, yaitu antara lain mempercepat penyusunan Perda, mengubah tarif, khususnya tarif retribusi dan peningkatan SDM.

3) Meningkatkan pengawasan; Hal ini dapat ditingkatkan yaitu antara lain dengan melakukan pemeriksaan secara dadakan dan berkala, memperbaiki proses pengawasan, menerapkan sanksi terhadap penunggak pajak \& sanksi terhadap pihak fiskus, serta meningkatkan pembayaran pajak dan pelayanan yang diberikan oleh daerah.

4) Meningkatkan efisiensi administrasi dan menekan biaya pemungutan; Tindakan yang dilakukan oleh daerah yaitu antara lain memperbaiki prosedur administrasi pajak 
melalui penyederhanaan admnistrasi pajak, meningkatkan efisiensi pemungutan dari setiap jenis pemungutan.

5) Meningkatkan kapasitas penerimaan melalui perencanaan yang lebih baik; Hal ini dapat dilakukan dengan meningkatkan koordinasi dengan instansi terkait di daerah.

\section{Penentuan Prioritas Kebijakan Dalam Optimalisasi Sumber-sumber PAD}

Dalam penentuan prioritas kebijakan dalam optimalisasi terhadap sumber-sumber pendapatan asli daerah Kabupaten Pegungunan Arfak digunakan analisis Analytical Hierarchy Process (AHP) atau Proses Hirarki Analitik. AHP dapat digunakan dalam memecahkan berbagai masalah diantaranya menentukan peringkat beberapa alternatif, melaksanakan perencanaan ke masa depan dan menetapkan prioritas kebijakan terkait dengan optimalisasi sumber-sumber pendapatan asli daerah.

Adapun struktur hirarki penentuan skala prioritas kebijakan dalam optimalisasi terhadap sumbersumber pendapatan asli daerah, dari hasil identifikasi kriteria kepada responden terdiri dari 3 (tiga) level. Yaitu Level pertama adalah tujuan yaitu Penentuan Skala Prioritas Kebijakan dalam optimalisasi terhadap sumber-sumber pendapatan asli daerah di Kabupaten Pegunungan Arfak, Level kedua adalah kriteria terdiri dari 4 kriteria yaitu : Pajak Daerah (PD), Restribusi Daerah (RD), Hasil Perusahaan Milik Daerah dan Hasil Pengelolaan Kekayaan Milik Daerah (HPMD \& PKMD) yang dipisahkan dan Lain-lain Pendapatan Asli Daerah Yang Sah (LPADS). Level ketiga merupakan alternatif kebijakan optimalisasi sumber-sumber pendapatan asli daerah tersebut yang terdiri dari : Memperluas basis penerimaan, memperkuat proses pemungutan, meningkatkan pengawasan, meningkatkan efisiensi administrasi dan menekan biaya pemungutan dan meningkatkan kapasitas penerimaan melalui perencanaan yang lebih baik.

Sementara secara keseluruhan Bobot dari masing-masing alternatif kebijakan pada masing-masing level (sumber-sumber pendapatan asli daerah) dengan metode Analytical Hierarchy Process (AHP) diperoleh prioritas kebijakan optimalisasi terhadap Sumber-Sumber Pendapatan Asli Daerah di Kabupaten Pegunungan Arfak seperti disajikan pada Tabel 1.

Tabel 1. Prioritas Kebijakan Optimalisasi Sumber-sumber PAD di Kabupaten Pegunungan Arfak

\begin{tabular}{|c|c|c|c|c|c|c|}
\hline \multirow[b]{2}{*}{ Kebijakan } & \multirow[b]{2}{*}{ PD } & \multicolumn{3}{|c|}{ Sumber PAD } & \multirow[b]{2}{*}{$\begin{array}{c}\text { Bobot } \\
\text { Nilai }\end{array}$} & \multirow[b]{2}{*}{ Prioritas } \\
\hline & & RD & $\begin{array}{c}\text { HPMD } \\
\& \\
\text { PKMD }\end{array}$ & LPADS & & \\
\hline $\begin{array}{l}\text { Meningkatkan kapasitas penerimaan } \\
\text { melalui perencanaan yang lebih baik }\end{array}$ & 0.2639 & 0.2286 & 0.2208 & 0.182 & 0.2238 & 1 \\
\hline Memperluas basis penerimaan & 0.2318 & 0.2408 & 0.2098 & 0.159 & 0.2103 & 2 \\
\hline $\begin{array}{l}\text { Meningkatkan efisiensi administrasi } \\
\text { dan menekan biaya pemungutan }\end{array}$ & 0.1987 & 0.1576 & 0.1682 & 0.247 & 0.1928 & 3 \\
\hline Memperkuat proses pemungutan & 0.1483 & 0.169 & 0.1503 & 0.279 & 0.1867 & 4 \\
\hline Meningkatkan pengawasan & 0.1574 & 0.2039 & 0.2509 & 0.133 & 0.1864 & 5 \\
\hline
\end{tabular}

\section{Sumber : Hasil Analisis, Olahan Data}

Penilaian terhadap beberapa alternatif kebijakan optimalisasi sumber-sumber pendapatan asli daerah dengan mempertimbangkan secara keseluruhan kriteria yang ada maka kebijakan optimalisasi sumber-sumber pendapatan asli daerah di Kabupaten Pegunungan Arfak adalah sebagai berikut :

1) Meningkatkan kapasitas penerimaan melalui perencanaan yang lebih baik merupakan prioritas kebijakan utama dalam optimalisasi sumber-sumber pendapatan asli daerah dengan pengaruh tingkat kepentingan terbesar yaitu dengan bobot $0,2238(22,38 \%)$

2) Memperluas basis penerimaan yang memiliki pengaruh tingkat kepentingan kedua dengan bobot $0,2103(21,03 \%)$
3) Meningkatkan efisiensi administrasi dan menekan biaya pemungutan sebagai prioritas kebijakan ketiga dengan bobot 0,1928 $(19,28 \%)$

4) Memperkuat proses pemungutan sebagai prioritas kebijakan keempat dengan bobot $0,1867(18,67 \%)$, dan

5) Meningkatkan pengawasan menempati prioritas kebijakan kelima dengan bobot $0,1864(18,64 \%)$.

Secara keseluruhan dari hasil Analytical Hierarchy Process (AHP) bobot penilaian hirarki skala prioritas kebijakan optimalisasi sumber-sumber PAD Kabupaten Pegunungan Arfak disajikan pada Gambar 1. 


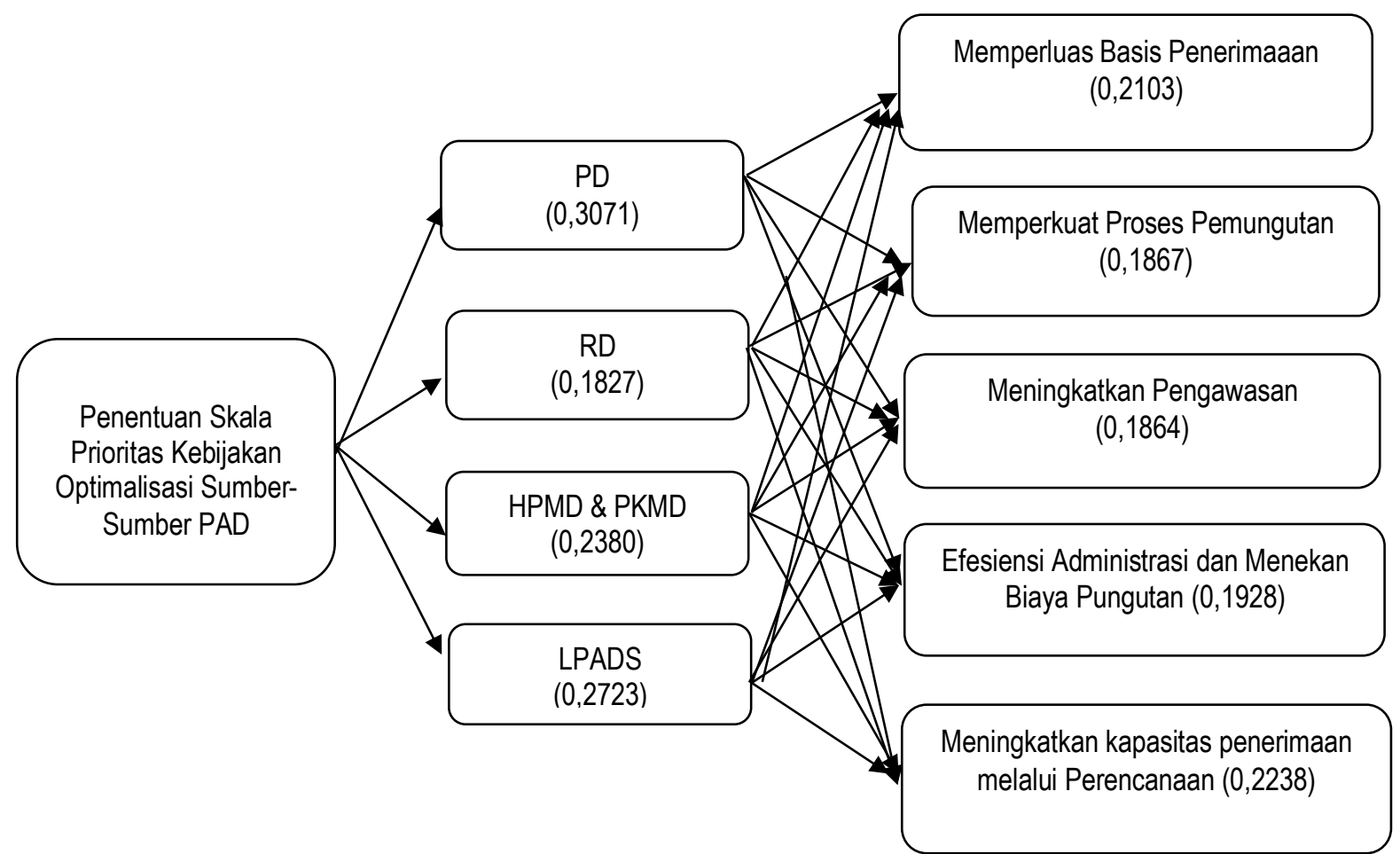

Sumber : Hasil Analisis, Olahan Data

Gambar 1. Bobot Penilaian Hirarki Skala Prioritas Kebijakan Optimalisasi Sumber-Sumber PAD Kabupaten Pegunungan Arfak

Persepsi Antar Stakeholder Terhadap Permasalahan Pengelolaan PAD Di Kabupaten Pegunungan Arfak

Kabupaten Pegunungan Arfak sebagai suatu daerah otonom yang secara administratif terbentuk pada tahun 2012 diharapkan memiliki kemandirian dalam keuangan daerah. Kabupaten Pegunungan Arfak dengan kewenangan yang dimiliki diharapkan pula mampu mengelola dan menggunakan keuangan sendiri yang cukup memadai untuk membiayai penyelenggaraan pemerintahan daerahnya. Namun dalam pelaksanaanya dari aspek pengelolaan, pemerintah daerah Kabupaten Arfak masih menghadapi hambatan atau permasalahan.

Dengan adanya penilaian terhadap persepsi antar stakeholder terhadap pengelolahan pendapatan asli daerah di Kabupaten Pegunungan Arfak mengungkapkan beberapa permasalahan yang dihadapi dalam upaya mencapai kemandirian keuangan daerah. Adapun secara garis besar permasalahan belum optimalnya pengelolahan pendapatan asli daerah di Kabupaten Pegunungan Arfak disajikan pada Tabel 2.

\section{Strategi Kebijakan Dan Program Optimalisasi Sumber-sumber PAD}

Keberhasilan pengelolaan pendapatan asli daerah tidak hanya semata diukur dari jumlah penerimaan yang dapat dicapai, tetapi sejauh mana pendapatan asli daerah tersebut dapat berperan mengatur perekonomian masyarakat agar dapat bertumbuh kembang yang pada gilirannya dapat meningkatkan kesejahteraan masyarakat di daerah. Secara teoritis kemampuan keuangan daerah dapat ditingkatkan dengan intensifikasi dan atau ekstensifikasi.

Upaya intensifikasi merupakan upaya meningkatkan kemandirian penerimaan daerah dengan meningkatkan kinerja sumber pendapatan asli daerah yang ada. Upaya ini menuntut kemampuan daerah untuk dapat mengidentifikasi secara sahib potensi penerimaan daerah dan kemudian mampu memungutnya dengan berdasar pada asas manfaat dan asas keadilan.Lebih lanjut, untuk mencapai hal tersebut berbagai sumber daya (software dan hardware) yang digunakan untuk memungut dan strategi pemungutan perlu segera disiapkan. Sedangkan upaya ekstensifikasi merupakan upaya perluasan jenis pungutan. Upaya ini harus dilakukan dengan hati-hati dengan mempertimbangkan berbagai aspek kepentingan ekonomi daerah dan nasional.

Secara umum, kebijakan yang perlu ditempuh oleh Pemerintah Daerah Kabupaten Pegunungan Arfak dalam rangka meningkatkan pendapatan daerah melalui optimalisasi sumber-sumber 
pendapatan asli daerah, antara lain dapat dilakukan dengan cara-cara sebagai berikut :

Tabel 2. Hasil Kompilasi Persepsi Stakeholders tentang Permasalahan Pengelolahan Pendapatan Asli Daerah di Kabupaten Pegunungan Arfak

\begin{tabular}{|c|c|}
\hline No. & Permasalahan \\
\hline 1 & $\begin{array}{l}\text { Terbatasnya kewenangan Pemerintah Daerah dalam mengelola jenis-jenis sumber pendapatannya. Terdapat } \\
\text { banyak jenis pelayanan yang cukup potensil untuk menjadi sumber pendapatan dari sektor rtribusi namun } \\
\text { belum diatur dalam Undang-Undang sehingga tidak dapat dipungut daerah }\end{array}$ \\
\hline 2 & Sumber-sumber pendapatan yang potensinya besar masih dikuasai oleh Pemerintahan Pusat \\
\hline 3 & $\begin{array}{l}\text { Bagi hasil pendapatan yang diterima oleh Pemerintah Daerah dari Pemerintah Pusat belum mencerminkan } \\
\text { aspek pemerataan dan pendistribusian hasi-hasil kekayaan daerah secara adil dan merata }\end{array}$ \\
\hline 4 & $\begin{array}{l}\text { Asset daerah yang potensil sebagai sumber pandapatan belum menghasilkan PAD sebagaimana yang } \\
\text { diharapkan }\end{array}$ \\
\hline 5 & Perusahaan Daerah dirasa masih belum optimal dalam memberi kontribusi sebagai penghasil PAD \\
\hline 6 & $\begin{array}{l}\text { Pertisipasi BUMN / Perusahan Swasta Nasional yang beroperasi di Kabupaten Pegunungan Arfak belum } \\
\text { memadai dalam mendukung ketersediaan dana pembangunan }\end{array}$ \\
\hline 7 & $\begin{array}{l}\text { Relatif rendah dan kurang berkembangnya basis, struktur serta jenis pajak dan retribusi daerah. Berdasarkan } \\
\text { UU No.34 Tahun } 2000 \text { daerah Kabupaten/Kota dimungkinkan untuk menetapkan jenis pajak dan retribusi } \\
\text { baru.Namun, melihat kriteria pengadaan pajak baru sangat ketat, khususnya kriteria pajak daerah tidak boleh } \\
\text { tumpang tindih dengan Pajak Pusat dan. Pajak Propinsi, diperkirakan daerah memiliki basis pungutan yang } \\
\text { relatif rendah dan terbatas, serta sifatnya bervariasi antar daerah. Rendahnya basis pajak ini memperkecil } \\
\text { kemampuan manuver keuangan daerah dalam menghadapi krisis ekonomi }\end{array}$ \\
\hline 8 & $\begin{array}{l}\text { Rendahnya kesadaran masyarakat dalam memenuhi kewajibannya membayar pajak, retribusi dan pungutan } \\
\text { lainnya }\end{array}$ \\
\hline 9 & $\begin{array}{l}\text { Perangkat hukum dan law enforcement terkait PAD yang mendukung pelaksanaan pemungutan pendapatan } \\
\text { yang belum baik yang perlu disesuaikan dan disempurnakan baik besaran tarifnya maupun sistem } \\
\text { pemungutannya }\end{array}$ \\
\hline 10 & Belum lengkapnya data base tentang pajak dan retribusi daerah \\
\hline 11 & $\begin{array}{l}\text { Terbatasnya kemampuan keuangan daerah, sehingga penerapan teknologi informasi dalam pengelolaan PAD } \\
\text { masih rendah dan sarana pelayanan belum memadai }\end{array}$ \\
\hline 12 & $\begin{array}{l}\text { Kemampuan administrasi pemungutan di daerah yang masih rendah Hal ini mengakibatkan bahwa } \\
\text { pemungutan pajak cenderung dibebani oleh biaya pungut yang besar. PAD masih tergolong memiliki tingkat } \\
\text { buoyancy yang rendah. Salah satu sebabnya adalah diterapkan sistem "target" dalam pungutan daerah. } \\
\text { Sebagai akibatnya, beberapa daerah lebih condong memenuhi target tersebut, walaupun dari sisi pertumbuhan } \\
\text { ekonomi sebenarnya pemasukkan pajak dan retribusi daerah dapat melampaui target yang ditetapkan }\end{array}$ \\
\hline 13 & $\begin{array}{l}\text { Kurangnya koordinasi internal dan dengan unit kerja lain yang berkaitan dengan pemungutan pajak dan } \\
\text { retribusi daerah }\end{array}$ \\
\hline 14 & $\begin{array}{l}\text { Kemampuan perencanaan dan pengawasan keuangan yang lemah hal ini mengakibatkan kebocoran- } \\
\text { kebocoran yang sangat berarti bagi daerah }\end{array}$ \\
\hline
\end{tabular}

Sumber: Hasil kompilasi wawancara di lapangan (data diolah)

1) Memperluas basis penerimaan

Program yang dilakukan untuk memperluas basis penerimaan yang dapat dipungut oleh daerah, yang dalam perhitungan ekonomi dianggap potensial, antara lain yaitu :

a) Melakukan identifikasi pembayar pajak baru/potensial dan jumlah pembayar pajak

b) Memperbaiki basis data objek, memperbaiki penilaian, menghitung kapasitas penerimaan dari setiap jenis pungutan.

2) Memperkuat proses pemungutan

Program yang dapat dilakukan dalam memperkuat proses pemungutan, yaitu antara lain :

a) Mempercepat penyusunan Perda terkait PAD

b) Mengubah tarif khususnya tarif retribusi

c) Peningkatan Kapasitas pengelola penerimaan melalui: Pelatihan tenaga pengelola, Penetapan kinerja tenaga penglola, Pemenuhan aspek kesejahteraan tenaga pengelola (gaji, upah pungut, karir dan sistem pensiun).

d) Meningkatkan kesadaran wajib pajak/retribusi melalui pendekatan persuasif-partisipatif, penyuluhan pajak clan retribusi disertai pelaksanaan pelayanan prima.

3) Meningkatkan pengawasan

Program yang dapat dilakukan dalam meningkatkan pengawasan yaitu antara lain :

a) Melakukan pemeriksaan secara dadakan (Sidak) dan berkala

b) Memperbaiki proses pengawasan

c) Menerapkan sanksi terhadap penunggak pajak dan sanksi terhadap pihak fiskus secara konsisten

4) Meningkatkan efisiensi administrasi dan menekan biaya pemungutan 
Program yang dapat dilakukan oleh daerah yaitu antara lain :

a) Memperbaiki prosedur administrasi pajak melalui penyederhanaan admnistrasi pajak

b) Meningkatkan efisiensi pemungutan dari setiap jenis pemungutan.

5) Meningkatkan kapasitas penerimaan melalui perencanaan yang lebih baik.

Program peningkatkan kapasitas penerimaan melalui perencanaan yang lebih baik ni dapat dilakukan dengan:

a) Memetakan potensi penerimaan.Hal ini dilakukan untuk memperoleh informasi mengenai kondisi keuangan daerah, khususnya terkait dengan sumber penerimaan yang berasal dari pelaksanaan pemungutan pajak daerah dan retribusi daerah serta kontribusinya terhadap keuangan dan perekonomian daerah.

b) Meningkatkan koordinasi dengan instansi terkait di daerah, satuan kerja perangkat daerah (SKPD) dengan cara menggali clan mengembangkan potensi sumber keuangannya sendiri, khususnya yang bersumber dari pajak dan retribusi daerah.

Berdasarkan uraian tersebut di atas, penyelenggaraan otonomi daerah akan dapat dilaksanakan dengan baik apabila didukung dengan sumber-sumber pembiayaan yang memadai. Potensi ekonomi daerah sangat menentukan dalam upaya untuk meningkatkan kemampuan keuangan daerah bagi penyelenggaraan rumah tangganya.

\section{PENUTUP}

\section{Kesimpulan}

1) Penilaian prioritas kebijakan optimalisasi terkait dengan Pajak Daerah menunjukkan bahwa meningkatkan kapasitas penerimaan melalui perencanaan yang lebih baik merupakan prioritas kebijakan utama dalam optimalisasi Pajak Daerah sebagai sumber PAD Kabupaten Pegunungan Arfak dengan pengaruh tingkat kepentingan terbesar yaitu dengan bobot 0,2639 (26,39\%), kemudian disusul dengan memperluas basis penerimaan sebagai prioritas kebijakan kedua, meningkatkan efisiensi administrasi dan menekan biaya pemungutan sebagai prioritas kebijakan ketiga, meningkatkan pengawasan sebagai prioritas kebijakan keempat dan memperkuat proses pemungutan menempati prioritas kebijakan kelima dengan bobot $0,1483(14,83 \%)$.
2) Penilaian terhadap prioritas kebijakan optimalisasi terkait dengan Restribusi Daerah menunjukkan bahwa memperluas basis penerimaan merupakan prioritas kebijakan utama dalam optimalisasi Restribusi Daerah sebagai sumber PAD Kabupaten Pegunungan Arfak dengan pengaruh tingkat kepentingan terbesar yaitu dengan bobot $0,2408(24,08 \%)$, kemudian disusul dengan meningkatkan kapasitas penerimaan melalui perencanaan yang lebih baik sebagai prioritas kebijakan kedua, meningkatkan pengawasan sebagai prioritas kebijakan ketiga, memperkuat proses pemungutan sebagai prioritas kebijakan keempat dan meningkatkan efisiensi administrasi dan menekan biaya pemungutan menempati prioritas kebijakan kelima dengan bobot $0,1576(15,76 \%)$.

3) Penilaian terhadap prioritas kebijakan optimalisasi terkait dengan Perusahaan Milik Daerah dan Hasil Pengelolaan Kekayaan Milik Daerah menunjukkan bahwa meningkatkan pengawasan merupakan prioritas kebijakan utama dalam optimalisasi Perusahaan Milik Daerah dan Hasil Pengelolaan Kekayaan Milik Daerah sebagai sumber PAD Kabupaten Pegunungan Arfak dengan pengaruh tingkat kepentingan terbesar yaitu dengan bobot 0,2509 (25,09\%), kemudian disusul dengan meningkatkan kapasitas penerimaan melalui perencanaan yang lebih baik sebagai prioritas kebijakan kedua, memperluas basis penerimaan sebagai prioritas kebijakan ketiga, meningkatkan efisiensi administrasi dan menekan biaya pemungutan sebagai prioritas kebijakan keempat dan memperkuat proses pemungutan menempati prioritas kebijakan kelima dengan bobot $0,1503(15,03 \%)$.

4) Penilaian terhadap prioritas kebijakan optimalisasi terkait dengan Lain-lain PAD Yang Sah menunjukkan bahwa memperkuat proses pemungutan merupakan prioritas kebijakan utama dalam optimalisasi Lain-lain Pendapatan Asli Daerah Yang Sah sebagai sumber pendapatan asli daerah Kabupaten Pegunungan Arfak dengan pengaruh tingkat kepentingan terbesar yaitu dengan bobot $0,2790(27,90 \%)$, kemudian disusul dengan meningkatkan efisiensi administrasi dan menekan biaya pemungutan sebagai prioritas kebijakan kedua, meningkatkan kapasitas penerimaan melalui perencanaan yang lebih baik sebagai prioritas kebijakan ketiga, memperluas basis penerimaan sebagai 
prioritas kebijakan keempat dan meningkatkan pengawasan menempati prioritas kebijakan kelima dengan bobot $0,1333(13,33 \%)$.

5) Penilaian terhadap beberapa alternatif kebijakan optimalisasi sumber-sumber PAD dengan mempertimbangkan secara keseluruhan kriteria yang ada maka kebijakan optimalisasi sumber-sumber PAD di Kabupaten Pegunungan Arfak adalah Meningkatkan kapasitas penerimaan melalui perencanaan yang lebih baik merupakan prioritas kebijakan utama dalam optimalisasi sumber-sumber pendapatan asli daerah dengan pengaruh tingkat kepentingan terbesar yaitu dengan bobot $0,2238(22,38 \%)$, memperluas basis penerimaan yang memiliki pengaruh tingkat kepentingan kedua, meningkatkan efisiensi administrasi dan menekan biaya pemungutan sebagai prioritas kebijakan ketiga, memperkuat proses pemungutan sebagai prioritas kebijakan keempat dan meningkatkan pengawasan menempati prioritas kebijakan kelima dengan bobot $0,1864(18,64 \%)$.

\section{Saran}

1) Optimalisasi sumber-sumber penerimaan perlu dilakukan untuk meningkatkan kemampuan keuangan daerah Kabupaten Pegunungan Arfak. Untuk itu diperlukan intensifikasi dan ekstensifikasi subyek dan obyek pendapatan.

2) Dalam jangka pendek kegiatan yang paling mudah dan dapat segera dilakukan adalah dengan melakukan intensifikasi terhadap obyek atau sumber pendapatan daerah yang sudah ada terutama melalui pemanfaatan teknologi informasi. Dengan melakukan efektivitas dan efisiensi sumber atau obyek pendapatan daerah, maka akan meningkatkan produktivitas penerimaan daerah tanpa harus melakukan perluasan sumber atau obyek pendapatan baru yang memerlukan studi, proses dan waktu yang panjang.

3) Dalam jangka panjang kegiatan yang dapat segera dilakukan adalah melakukan ekstensifikasi terhadap obyek atau sumber pendapatan daerah yang baru melalui penggalian potensi baru yang didukung oleh sistem informasi basis data. Upaya ini harus dilakukan dengan hati-hati dengan mempertimbangkan berbagai aspek kepentingan ekonomi daerah dan nasional.

\section{Rekomendasi}

1) Dalam jangka pendek upaya peningkatan penerimaan daerah hanya mampu meletakkan dasar-dasar yang mengarah pada penerimaan daerah yang "benar" dan mencerminkan fungsi pemerintah daerah. Peningkatan penerimaan daerah yang tidak terarah dan benar (hanya bersifat jangka pendek dan untuk kepentingan kelompok tertentu) justru akan menjatuhkan kewibawaan pemerintah daerah di mata publik yang pada gilirannya akan menurunkan kesejahteraan masyarakat daerah. Oleh karena itu penentuan potensi (penyusunan basis data potensi) setiap jenis penerimaan daerah secara benar dan penerapan sistem dan prosedur koleksi penerimaan daerah yang sesuai dengan situasi dan kondisi masyarakat daerah setempat serta pengawasan yang benar-benar akan mampu mengoptimalisasi peningkatan penerimaan daerah.

2) Dukungan teknologi informasi secara terpadu guna mengintensifkan pajak mutlak diperlukan karena sistem pemungutan pajak yang dilaksanakan selama ini cenderung tidak optimal. Masalah ini tercermin pada sistem dan prosedur pemungutan yang masih konvensional dan masih banyaknya sistem berjalan secara parsial (kurang koordinasi), sehingga besar kemungkinan informasi yang disampaikan tidak konsisten, versi data yang berbeda dan data tidak up-to-date. Permasalahan pada sistem pemungutan pajak cukup banyak, misalnya: baik dalam hal data wajib pajak/retribusi, penetapan jumlah pajak, jumlah tagihan pajak dan target pemenuhan pajak yang tidak optimal.

3) Mengoptimalkan potensi pengenaan pajak dengan melakukan inventarisasi secara mendalam dan berkelanjutan tetapi tidak mengabaikan good corporate government dalam segala lini. Mengoptimalisasi pengenaan pajak baik lama maupun potensi pajak baru tentulah harus mengedepankan fleksibilitas kearifan lokal yang telah berlaku di masyarakat Kabupaten Pengunungan Arfak.

4) Menyusun Peraturan Daerah (Perda) yang berkaitan dengan Pendapatan Asli Daerah.

5) Dengan adanya potensi pariwisata yang ada di Kabupaten Pegunungan Arfak, Pemerintah diharapkan segera menyusun Rencana Induk Pengembangan Pariwisata Daerah (RIPPDA).

6) Pembentukan kelembagaan yang tugas dan kewenangannya untuk menggali potensi yang berkaitan dengan sumber-sumber 
pengembangan PAD di Kabupaten

Pegunungan Arfak.

\section{DAFTAR PUSTAKA}

Adisasmita, R. (2005). Dasar-Dasar Ekonomi Wilayah, Graha Ilmu, Yogyakarta.

Ahmad, Yani, 2008, Hubungan Keuangan Antara Pemerintah Pusat dan Daerah, Jakarta: Grafindo

Arsyad, Lincolin. (1999). Pengantar Perencanaan dan Pembangunan Ekonomi Daerah. BPFE, Yogyakarta.

Ateng Syafrudin. (2000). Langkah Awal Reformasi Otonomi Daerah. Makalah Seminar Bandung, Universitas Winaya Mukti, Bandung.

Balitbang, Provinsi Sumut. (2010). Penelitian dan Pengembangan Provinsi Sumatera Utara, 2010, Kajian Sistem Database Potensi Pendapatan Asli Daerah (PAD) Di Sumatera Utara, Medan

Bappeda Kabupaten Kuningan, Lembaga Penelitian Unswagati. (2012). Upaya Peningkatan Pendapatan Asli Daerah Melalui Sektor Pariwisata di Kabupaten Kuningan, Cirebon

Bappeda Kabupaten Palangka Raya. (2011). Analisis dan Kajian Terhadap Potensi Pendapatan Asli Daerah (PAD) dalam Rangka Mengoptimalkan PAD di Kota Palangka Raya., Palangka Raya

Bappeda Kabupaten Pegunungan Arfak. (2014). Profil Kabupaten Pegunungan Arfak 2014, Bappeda Pegaf.

Bhenyamin Hoessein. (2000). Otonomi Daerah, Akademisi, Vol. I No. 4, Jakarta.

Bird, Richard M. dan Francois Vaillancourt. (2000). Desentralisasi Fiskal di NegaraNegara Berkembang, Penerbit PT. Gramedia Pustaka Utama, Jakarta.

Booth, Anne. (2002). Upaya-upaya untuk Mendesentralisasikan Kebijaksanaan Perpajakan: Masalah Kemampuan Perpajakan, Usaha Perpajakan dan Perimbangan keuangan. Hubungan Pusat Daerah dalam Pembangunan. (Editor: Colin Mac Andrews dan Ichlasul Amal), Penerbit PT. Raja Grafindo Persada, Jakarta.

Halim, Abdul. (2001). Akuntansi dan Pengendalian Keuangan Daerah. UPP AMP YKPN, Yogyakarta.

Halim, Abdul. (2004). Akuntansi Keuangan Daerah, Edisi Ketiga. Salemba Empat, Jakarta.
Halim, Abdul. (2004). Manajemen Keuangan Daerah. UPP AMP YKPN, Yogyakarta

Hastanti, Baharinawati W. (2014) Strategi pengelolaan Cagar Alam Pegunungan Arfak menurut kearifan lokal masyarakat di Manokwari Papua Barat. Malang: Universitas Negeri Malang

Hidayat. Syarif. (2000). Refleksi Realitas Otonomi Daerah dan Tantangan ke Depan. Pustaka Quantum, Jakarta

Hukumonline.Com, (2014), Undang-Undang Republik Indonesia Nomor 24 Tahun 2012 Tentang Pembentukan Kabupaten Pegunungan Arfak Di Provinsi Papua Barat, Hukumonline.Com

Mardiasmo. (2004). Otonomi dan Pembangunan Daerah. Andi, Yogyakarta.

Nogi.S, Hessel. (2005). Manajemen Publik. Grafindo, Jakarta.

Republik Indonesia. (2012). Undang-Undang Pembentukan Kabupaten Pegunungan Arfak. Jakarta: Sekretariat Negara

Sobandi, Baban. (2003). Strategi Optimalisasi Pendapatan Asli Daerah (PAD): Kasus Kota Banjarmasin, Banjarmasin

Tim Penyusun. (2013). Profil Kabupaten Pegunungan Arfak 2013. Manokwari: PT. Cordenta Consultama

Tim Penyusun. (2013). Kabupaten Manokwari Dalam Angka Tahun 2013. Manokwari: Biro Pusat Statistik

Tim Penyusun. (2014). Rencana Tata Ruang Wilayah Kabupaten Pegunungan Arfak 2014 -2034. Jakarta

Umar, Asri. (2000). Dampak UU No. 32/2004 tentang Pemerintah Daerah dan UU No. 33/2004 tentang Perimbangan Keuangan Pusat dan Daerah terhadap Sistem Pertanggungjawaban Keuangan Daerah, Makalah bagi Seminar Sistem Akuntansi dan Pelaporan Keuangan Daerah, Jakarta.

Wardhono, Adhitya. (2012). Kajian Pemetaan dan Optimalisasi Potensi Pajak dalam Rangka Meningkatkan Pendapatan Asli Daerah (PAD) di Kabupaten Jember, J@Ti Undip, Vol VII, No 2, Fakultas Ekonomi, Jurusan Ilmu Ekonomi Universitas Jember, Jember

Winarso, Harso. 2010, Kebudayaan Masyarakat Arfak. Universitas Parahyangan, Bandung. 